\title{
A Study of Problems Faced by Indonesian Employees at PT. Doosan Jaya Sukabumi in Writing English Business Documents
}

\author{
Lina Herlina
}

Nusa Putra University, Sukabumi, Indonesia

*Corresponding author. E-mail: lina.herlina@nusaputra.ac.id

\begin{abstract}
This study aims to investigate problems faced by Indonesian employees at PT. Doosan Jaya Sukabumi in writing English business documents. The investigation aimed to identify the primary issues and recommend improving the employees' English writing skills. Purposive and quota sampling strategies were used in the study. The total number of respondents was 32, and they worked in industries such as accountancy, sales and marketing, logistics, and production, all of which commonly employ English in the workplace. Due to a shortage of time, our research focussed on finding challenges with writing business e-mails, letters, and reports. The results suggest that at PT. Doosan Jaya Sukabumi's most prevalent problems with drafting business e-mails were the lack of advanced vocabulary and grammatical knowledge. At the same time, poor time management, clarity, and tone words had become the most common problems faced by the employees in writing business letters. The significant problem that the employees dealt with in writing their reports was the lack of knowledge of business writing. They faced difficulties in constructing sentences and paragraphs properly. According to the result of the study, the employees in the mentioned departments are advised to take an English writing course at the language center, have the corporation give in-house training in English writing skills, or do self-study.
\end{abstract}

Keywords: Writing Skills, English Business Documents, Problems in English Writing.

\section{INTRODUCTION}

English has become a critical skill in this era of globalization, and many businesses expect staff to have strong English abilities, particularly in writing, due to the increased demand for written communication in the corporate sector. According to [17], People from other nations need to connect more than ever before, and English is frequently utilized for intercultural communication.

English has played an essential role in business and the international workplace. Therefore, English communication skills have become a requirement for almost all professionals, especially global companies. They are the key to successful careers and organizations.

One of the English communication skills related to companies' needs is writing skills. This is a crucial talent because individuals use it to communicate thoughts, ideas, and sentiments to build strong relationships and mutual understanding [8].

PT. Doosan Jaya Sukabumi is a Korean company located in Sukabumi district, West Java, Indonesia. Founded in 2002, this company is one of the export-oriented companies in Indonesia. It produces lady's blouses, jackets, skirts, and pants. The products are exported to South Korea, Japan, and some other countries in Asia, the United States, and most countries in Europe, and the business has been expanding rapidly [7].

The production of big and medium manufacturing industries (IBS) increased 4.45 percent in the first quarter of 2019 compared to the same time the previous year, according to data from the Central Statistics Agency (BPS). The growth in IBS output was aided by a 29.19 percent increase in clothing industry production, owing to an oversupply of orders, particularly from the export market, which provided additional export prospects for developing nations [11]. As a result, the staff of 
PT. Doosan Jaya Sukabumi is required to communicate in English for business purposes.

The researcher carried out an initial observation at PT. Doosan Jaya Sukabumi found that Employees in practically every department at PT. Doosan Jaya Sukabumi is needed to use English, primarily written English, because they must send emails, letters, and reports in English both inside the firm and to others such as suppliers, clients, and shipping agents. After observing some business documents written in English, the researcher found grammatical errors, incorrect diction, and unstructured paragraphs in the sample business documents. These probably lead to misunderstanding, which may bring about unsuccessful business.

Therefore, this study aims to investigate problems faced by Indonesian employees at PT. Doosan Jaya Sukabumi in writing English business documents and providing recommendations improve the employees' English writing skills.

\section{LITERATURE REVIEW}

In good business communications, according to [9], The text should be simple to read and absorb, with no superfluous words, phrases, or even paragraphs. To increase readability, headers, bulleted lists, side headings, and an introduction that summarizes what will follow should all be utilized. Cliches, jargon, and slang that contribute to international miscommunication should be avoided; the substance should be exact and correct in language. Prior to submission, the author should double-check their work and make use of the checking tool.

According to [2], a excellent author should be able to write for 12 hours a day, year after year. It is preferable to make writing a straightforward daily routine rather than being compelled to write hour after hour. According to [4], the most common issues with writing ability are grammar and sentence form. According to [19], written communication is time-consuming and accounts for 30 percent of the labor. It is vital to enhance writing skills for time efficiency and the success that may depend on it.

According to [21], the biggest issue with utilizing English is the inability to employ proper grammar. Even though most staff had worked with foreigners for many years, conveying thoughts or ideas using adequate language was not easy. Furthermore, technical words, slang, and idiomatic phrases are difficult to comprehend.

Employers frequently complain about their workers' writing skills; according to [14], MBA students' responses on a course assignment were examined by Lentz. Their writing talents and deficiencies were evaluated, and the results indicated that companies must conduct an adequate evaluation of their employees' writing abilities.

Employees at Electronics Sources Co., Ltd, according to [24], had a lot of trouble utilizing proper syntax, sentence structure, vocabulary, and technical words. They also encountered issues with data and content presentation.

According to [17], Thai employees at Unicord Public Co., Ltd. were proficient in drafting business e-mails. However, they did have issues with utilizing acceptable sentences, such as employing outmoded idioms and a lack of conciseness.

Employees at a Thai-Japanese leasing firm, according to [20], faced communication issues with Japanese personnel when it came to composing emails. The difficulties stemmed from writing e-mails with proper grammar and the inability to utilize many terms without consulting a dictionary. Employees at The Classic Chairs Company have difficulty producing e-mails, letters, and reports, according to [5], due to a lack of language, grammatical understanding, and time management. Secretaries in companies are suggested that they attend English education or training, install English dictionary app, listen to English songs or watch English videos, join online learning communities and participate in international organization forum activities [6].

\section{RESEARCH METHODS}

The population was the employees at PT. Doosan Jaya Sukabumi. The study acquired purposive and quota sampling methods. Accounting, Sales \& Marketing, Logistics, and Production were among the 32 employees that responded to the survey. Employees in these four divisions were Indonesians who used written English more frequently than others to interact with both Indonesians and foreigners at their internal and external workplaces.

The researcher created a questionnaire to examine the issues with drafting English business papers to gather information. The questionnaire was given to the respondents, and they were requested to fill it out. The surveys were gathered when respondents filled them out within five days after receiving them. The questionnaire contained closed (part 1 and part 2) and opened questions (part 3). The closed-ended questions answers are analyzed using SPSS: 
1) The answers to part 1 questions were analyzed using frequency distribution and percentage.

2) A five-point Likert Scale was used to score the part 2 questions from "Strongly Agree" to "Strongly Disagree," as shown in table 1. The following formula was used to interpret the mean score findings.

Mean Range $=\frac{\text { Maximum }- \text { Minimum }}{\text { Range }}$

Mean Range $=\frac{5-1}{5}=0.8$

Table 1. Five-Point Likert Scale

\begin{tabular}{|c|c|}
\hline Scale & Mean Range \\
\hline $5=$ Strongly Agree & $4.21-5.00$ \\
\hline $4=$ Agree & $3.41-4.20$ \\
\hline $3=$ Not Sure & $2.61-3.40$ \\
\hline
\end{tabular}

\begin{tabular}{|c|c|}
\hline 2 = Disagree & $1.81-2.60$ \\
\hline $1=$ Strongly Disagree & $1.00-1.80$ \\
\hline
\end{tabular}

\section{RESULTS AND DISCUSSION}

The study's findings are separated into three sections: background information on respondents, challenges with utilizing written business English at work, and tips for improving English writing abilities.

\subsection{Respondents' Background}

The study's findings are separated into three sections: background information on respondents, challenges with utilizing written business English at work, and tips for improving English writing abilities.

Table 2. Respondents' Background

\begin{tabular}{|c|c|c|c|}
\hline Criteria & Details & Frequency & Percentage \\
\hline \multirow{2}{*}{ Gender } & Female & 22 & $69 \%$ \\
\hline & Male & 10 & $31 \%$ \\
\hline \multirow{6}{*}{ Age } & $20-25$ & 0 & $0 \%$ \\
\hline & $26-30$ & 6 & $19 \%$ \\
\hline & $31-35$ & 15 & $47 \%$ \\
\hline & $36-40$ & 8 & $25 \%$ \\
\hline & $41-45$ & 2 & $6 \%$ \\
\hline & $45-50$ & 1 & $3 \%$ \\
\hline \multirow{4}{*}{$\begin{array}{l}\text { Educational } \\
\text { Background }\end{array}$} & High School & 5 & $16 \%$ \\
\hline & Diploma & 10 & $31 \%$ \\
\hline & Bachelor's Degree & 15 & $47 \%$ \\
\hline & Master's Degree & 2 & $6 \%$ \\
\hline
\end{tabular}


Table 2 shows that the respondents consisted of $22(69 \%)$ female employees and $10(31 \%)$ male employees. The employees' age is various. The majority of the responders $(47 \%)$ were between the ages of 31 and $35,6(19 \%)$ were between 26 to 30 years old, and $8(25 \%)$ of them were between 36 to 40 years old. Two respondents were aged between 41 to 45 years old, and one respondent was between 45 to 50 years old. Most respondents held bachelor's degrees $(47 \%)$, and 2 of the respondents held master's degrees, while the rest held diplomas (31\%) and high school (16\%).

\subsection{Problems in Using Written Business English at the workplace}

Concerning difficulties with business e-mail writing, the majority of respondents (69 percent) agreed with the statement, "I am unable to utilize proper syntax in my business English e-mails." It shows that grammar had been their main problem in writing e-mails. The second main problem they faced in writing English business e-mails was vocabulary, as $67 \%$ of the respondents agreed with the statement, "I cannot use advanced vocabulary for my business English e-mails."

Based on the result, it is evident that the main problems faced by employees in writing English business e-mails were grammar and vocabulary. This is consistent with [4] and [20], who found that the inability to compose e-mails with acceptable grammar and a lack of speech was issued in e-mail writing. Furthermore, this conclusion confirms [5] The Classic Chairs Company's most frequent difficulty with business writing an e-mail was the inability to write grammatically correct emails, followed by the inability to use a broad range of vocabulary in their business English e-mail.

It can be seen from the questionnaire result concerning problems in writing English business letters. The employees faced the top four issues in writing business letters. They were time management, clarity, and tone words. $75 \%$ of the respondents agreed with the statement "I cannot take the time to write a business letter correctly," and $72 \%$ agreed with "I cannot write my business letter clearly and accurately." $69 \%$ of the respondent agreed with the statement "I cannot write in a business letter all the information needed to clarify the point and the necessary steps in the letter.", and 19 out of 32 respondents agreed with the statement "It is not easy for me to use appropriate words for my business letters."

The result shows that most of the employees at PT. Doosan Jaya Sukabumi had three main problems in writing English Business letters; time management, clarity, and tone words.

The study's findings support [2] assertion that one should write 12 hours a day to be a good writer every year. It is better to write a simple daily routine than to be forced to write for hours. The findings back with [19] claim that written communication takes time and accounts for $30 \%$ of the effort. It is vital to enhance writing skills for time efficiency and the success that may depend on it.

Concerning the problems in writing English business reports, most respondents (72\%) agreed with the statement "I cannot properly organize paragraphs in the annual report ."Twenty-two respondents (69\%) agreed with the word "I am unable to use sentence pattern correctly in the annual report," and the same number of the respondents also agreed with the statement "I am not able to write an annual report in clear text and simple words ."20 out of 32 respondents agreed with the statement, "I cannot use effective headings and subheadings in annual reports."

According to the result, the employees faced two significant problems writing English business reports. Those problems are related to sentence construction and paragraph construction. It shows that the employees lacked knowledge in business writing. This is consistent with the findings of [4], They discovered that the most frequently encountered difficulties with writing abilities are with grammar and sentence building, and [5], who found that the biggest problem with creating English reports from employees was with the correct use of sentence patterns in annual reports.

\subsection{Recommendation to Improve Employees' English Writing Skills at Workplace}

Part three of the questionnaire investigated the respondents' suggestions on improving employees' writing skills by asking them an open-ended question, "What would you like to do to improve your English writing skills at the workplace?".

The question was answered by 87 percent of the respondents. The recommendations of the responders are summarized in four points:

1) Ten respondents (31\%) suggested that the employees take an English writing course in a language center.

2) Eight respondents (25\%) proposed that the organization give in-house English writing skills training.

3) Seven respondents (22\%) said that employees should learn and practice independently 
regularly. Three respondents (9\%) suggested that the employees need to see business document examples on the internet.

The findings corroborate [2] that one should write 12 hours a day to be a good writer every year after that. It is better to write a simple daily routine than to be forced to write for hours.

\section{AUTHORS' CONTRIBUTIONS}

The study conceptualization and design, data collection, analysis and interpretation of results, and article writing are all solely the author's responsibility.

\section{ACKNOWLEDGMENTS}

First of all, I would like to express my most incredible gratitude to Allah SWT, the God Almighty who has given me strength and good health to carry out this study. Secondly, I sincerely express my great gratitude to the director of PT. Doosan Jaya Sukabumi and all participants from the company who participated in this study. Finally, my deepest gratitude is for my family's love, support, and encouragement throughout this investigation.

\section{REFERENCES}

[1] Baugh, L. Sue, M., \& David, T. Handbook for business writing, 2nd Ed. Lincolnwood, Illinois: NTC Business Books, 1994. 14259.

[2] Berger, A. Improving writings skills: Memos, letters, reports, and proposals. Sage Publication printed in United State of America, 1993.

[3] Bovée, Courtland L. \& John V. Thill. Business Communication Today. New Jersey: Prentice-Hall, 2000.

[4] Davis, P., McCormick, W.D., \& Hemphill, D.R. You and business communication: the communication theory, Business communication with writing improvement exercises (6th ed.). New Jersey: PrenticeHall, 2000

[5] Decharotchanawirun, T. "A Study of Problems in the Business English Writing Skills of Thai Employees at the Classic Chairs Company," Unpublished. Master of Arts in English for Careers Language Institute, Thammasat University Thailand, 2015 ,

http://ethesisarchive.library.tu.ac.th/thesis/20 15/TU_2015_5621030609_4583_2614.pdf.
[6] Dwihartanti, M. \& Faizah N. "Pentingnya Penguasaan Bahasa Inggris Bagi Pelaksanaan Tugas Rutin Sekretaris", in: Jurnal Efisiensi - Kajian Ilmu Administrasi, February Edition, 2018, Vol. XV No. 1, ISSN 1412-1131, e-ISSN 2528-5750, pp. 28-35

[7] Export Oriented Garment Companies in Indonesia. Apindo, 2019.

[8] Gale, P. Effective business writing: Top principles and techniques, 2014. Retrieved November 2021, from http://www.englishgrammar.org/effectivebusinesswriting/

[9] Guffey, M. \& Du-Babcock, B. Essentials of business communication. Singapore: Cengage Learning Asia Pte Ltd, 2010.

[10] Heydari, P. \& Bagheri, M. Error analysis: Sources of L2 learners' errors. Theory and practice in language studies, 2, 1583-1589, 2012.

[11] Kementerian Perindustrian Republik Indonesia. Siaran Pers: Lampaui 18 Persen, Industri Tekstil dan Pakaian Tumbuh Paling Tinggi. 2019. Retrieved November 2021.

[12] Klomperee, T. "A comparative study of the writing pattern of The Royal Thai Navy's letters and business letters," Unpublished. Master of Arts degree in Business for International Communication, Srinakharinwirot University, 2006.

[13] Kuntakhiaw, P. "Problems in communication via English business writing among sales persons working in an intercultural company," Independent Study, English for Careers, Language Institute, Thammasat University, 2011.

[14] Lentz, P. 'MBA students' workplace writing: Implications for business writing pedagogy and workplace practice," Business Communication Quarterly, 76(4), 2013.

[15] Limited, W. The Write Style Guide for New Zealanders: A manual for business editing. Wellington, New Zealand: Write Limited, 2013.

[16] Media, D. \& Suttle R. Importance of writing skills in business, 2015. Retrieved in November 2021 from http://smallbusiness.chron.com/importancewritingskills- business-845.html.

[17] Pathomchaiwat, T. "Proficiency of Thai staff at 
Unicord Public Co., Ltd in writing English business e-mails," Independent Study, English for Careers, Language Institute, Thammasat University, 2014.

[18] Pettersson, L. "Writing Business E-mails in English as a Lingua Franca - how informal can you be? An analysis of formality in BELF e-mails". Bachelor's Degree Project English Linguistics, Stockholm University, 2015.

[19] Prapawuttikul, J. "English writing and speaking needs analysis of MIT support staff," Unpublished. The University of the Thai Chamber of Commerce, Bangkok, Thailand, 2004.

[20] Santithawornying, N. "Problems in English communication skills between Thai and Japanese staff in a Thai-Japanese leasing company," Independent Study. English for Careers, Language Institute, Thammasat University, 2015.

[21] Srisitanon, P. "Intercultural communication problems of Thai Employees at Precious Shipping Public Company Limited (PSL)," Unpublished. Language Institute, English for Careers, Thammasat University, 2009.
[22] The Office of Investor Education and Assistance US Securities and Exchange Commission. A plain English handbook. Washington DC: Author, 1998.

[23] How to write a business report. The School of Marketing and International Business, and Student Learning. Victoria University of Wellington, 2016.

[24] Tanviboolaya, L. "Problems and needs in business English writing skills of employees at electronics source co., ltd," Independent Study. English for Careers, Language Institute, Thammasat University, 2014. 